Istanbul Finance Congress, November 1-2, 2018, Istanbul, Turkey.

\title{
FAMA-FRENCH FIVE FACTOR MODEL AND THE NECESSITY OF VALUE FACTOR: EVIDENCE FROM ISTANBUL STOCK EXCHANGE
}

\section{DOI: 10.17261/Pressacademia.2018.972}

PAP-IFC- V.8-2018(4)-p.14-17

\section{Nesrin Ozkan}

Bursa Uludağ University, Social Sciences Faculty, Business Administration, Bursa, Turkey. nsrozkn@gmail.com, ORCID : 0000-0002-8674-5518

\section{To cite this document}

Ozkan, N. (2018). Fama-French five factor model and the necessity of value factor: Evidence from Istanbul Stock Exchange. PressAcademia Procedia (PAP), V.8, p.14-17.

Permanent link to this document: http://doi.org/10.17261/Pressacademia.2018.972

Copyright: Published by PressAcademia and limited licenced re-use rights only.

\section{ABSTRACT}

Purpose- The objective of this paper is to test the validity of Fama and French (2015) five factor model in Istanbul Stock Exchange (ISE) and to determine whether the value factor is redundant in the model.

Methodology - To that end, Fama-French five factor model is primarily tested, which is composed of market, firm size, value, profitability and investment factors. Afterwards, the value factor is excluded from the model and the empirical performance of two models are compared. Multiple regression analysis is carried out by using time series data from July 2009 to June 2015. Besides that, GRS-F test is applied to determine the pricing errors in models.

Findings- The results show that Fama-French five factor model can be used in ISE in explaining the variation of returns, although the factor returns are lower in comparison with Fama and French (2015) findings. Specifically, the size premium is considerably lower attained. On the other hand, GRS-F test proves there is no pricing error in the model.

Conclusion- Finally, the model is found viable in ISE between the period of July 2009 and June 2015. It is further found that the value factor is not redundant in the Fama-French five factor model.

Keywords: Fama-French five factor model, asset pricing, returns, time series regression, ISE. JEL Codes: C19, G12, G14

\section{INTRODUCTION}

A long time after Fama-French three factor model, Fama ve French (2015) has added two new factors to the model and called it FamaFrench five factor model. Preliminary the profitability factor is added and later by adding investments, the new model is formed. Fama and French (2015) tested the model in NYSE, AMEX, NASDAQ and presented the validity of model between 1963 and 2013. However, the main problem of the new model is the value factor that becomes redundant after two newly added factors.

The new model is tested in international markets and the evidence mainly supports the validity of model (Nguyen et. al, 2015; Clarice and William, 2015; Cakıcı, 2015; Yang et. al,2017). On the other hand, some findings are quite different than Fama and French (2015) study, especially about the redundancy of value factor (Chiah et. al, 2016; Lin, 2017; Foye, 2018; Aragon et. al, 2018). In Turkey, a study is conducted by AcaravcI and Karaömer (2017) in ISE between the years of 2005 and 2016. The authors assert that GRS-F test proved the validity of five-factor model. However, they don't mention the necessity of value factor in the model. In order to fulfill the gap in literature, I retested Fama-French five factor also by excluding value factor for the period of 2009 and 2015.

\section{FAMA-FRENCH FIVE FACTOR MODEL}

In Fama-French five factor model, the excess return of a portfolio is explained by market, firm size, value, profitability and investment factors as described in regression equation below (Fama ve French, 2015: 2-3):

$$
R_{(t)}-R F_{(t)}=\alpha+b\left[R M_{(t)}-R F_{(t)}\right]+\mathrm{s} S M B_{(t)}+h H M L_{(t)}+r R M W_{(t)}+c C M A_{(t)}+e_{(t)}
$$

$\left[\left(\mathrm{RM}_{(\mathrm{t})}-\mathrm{RF}(\mathrm{t})\right)\right]$ : The return of market portfolio minus risk-free rate.

SMB : The difference between the returns of diversified portfolios of small stocks minus the returns of diversified portfolios of big stocks.

HML : The difference between the returns of diversified portfolios of high BE/ME (book equity to market equity) stocks minus the returns of diversified portfolios of low BE/ME stocks. 
RMW : The difference between the returns of diversified portfolios of robust profitability stocks minus the returns of diversified portfolios of weak profitability stocks.

CMA : The difference between the returns of diversified portfolios of low investment stocks minus the returns of diversified portfolios of high investment stocks.

Where, $\mathrm{RF}_{(\mathrm{t})}$ is risk-free rate, $\left[\mathrm{RM}_{(\mathrm{t})}-\mathrm{RF}(\mathrm{t})\right], \mathrm{SMB}, \mathrm{HML}, \mathrm{RMW}, \mathrm{CMA}$ are factor premiums and $\mathrm{b}, \mathrm{s}, \mathrm{h}, \mathrm{r}, \mathrm{c}$ are factor loadings.

\section{DATA SET AND METHODOLOGY}

The sample of study constitutes of nonfinancial firms listed in ISE during the period of July 2009 to June 2015 . Time series regression method is used in the analysis. Monthly adjusted stock prices and return series are from ISE and accounting data is from Public Disclosure Platform. The risk-free rate is three-month Treasury bill rate, obtained from the website of the Central Bank of the Republic of Turkey. Negative book equity firms and the firms with unavailable return or accounting data are excluded from the sample.

The factors are calculated and constructed by following the method of Fama and French (1993) and Fama and French (2015). SMB factor is calculated as per market capitalization of firms. Market capitalization of stocks is ranked in descending order and allocated to two portfolios as per median value. In order to constitute HML factor, stocks are ranked in accordance with BE/ME value and grouped in reference to NYSE breakpoints of \%30-\%40-\%30. Similarly, RMW and CMA factors are calculated and sorted in the manner of HML. Afterwards, six intersection portfolios are constructed from two size and three BE/ME groups. By taking the intersection of size and profitability groups attained six portfolios and also six portfolios are constituted from size and investment groups. The intersection portfolios are labelled as SL, SM, SH, BL, BM, BH, SR, SW, BR, BW, SC, SA, BC and BA and used in abbreviated form ${ }^{1}$. The excess return of portfolios are used as dependent variable and MKT, SMB, HML, CMA, RMW factors are independent variables in regression models.

The portfolios are constructed in June of each year $t$ and reconstituted each year. The value-weighted returns are calculated for each portfolio from July of year $t$ to June of year $t+1$. Gibbons, Ross and Shanken (1989) test used to determine if the alpha values are different than zero that imply pricing errors in the model. Furthermore, the average absolute value of alpha and adjusted $\mathrm{R}^{2}$ are used as performance measures.

\section{EMPIRICAL FINDINGS}

The analysis is carried out with nonfinancial firms in ISE between the years of 2009 and 2015 for totally 72 months. The summary statistics proved statistically and economically significant factor premiums. The highest factor premium is provided by market factor, while the lowest is firm size. In order to detect the autocorrelation and heteroskedasticity, White test and Breusch-Godfrey LM test are used ${ }^{2}$. Table 1 shows the correlation among the factors.

Table 1: Correlation Matrix

\begin{tabular}{llllll}
\hline & MKT & SMB & HML & CMA & RMW \\
\hline MKT & 1.000 & & & & \\
SMB & -0.025 & 1.000 & & & \\
HML & -0.014 & -0.487 & 1.000 & & \\
CMA & -0.043 & 0.520 & -0.489 & 1.000 & \\
RMW & -0.069 & -0.229 & 0.189 & -0.086 & 1.000 \\
\hline
\end{tabular}

Note: MKT, SMB, HML, CMA and RMW represent market, firm size, value, investment and profitability factors, respectively

In Table 1 the correlation between HML and CMA is quite high but not as high as Fama and French (2015) finding of 0.70 . Thereby it can be interpreted that no multicollinearity is observed among the factors.

Table 2 presents regression results of Fama-French five factor model. $F$ column indicates the overall significance of regression models and all the values of 14 regressions are significant at \%1 level. The lowest adjusted $R^{2}$ value is 0.410 and the highest value is 0.860 . The average adjusted $\mathrm{R}^{2}$ value is calculated 0.643 . In other words, $\% 64.3$ of the variation on excess portfolio returns are explained by explanatory variables.

Table 2: Fama- French Five Factor Model Regression Results

\begin{tabular}{|c|c|c|c|c|c|c|c|c|}
\hline \multicolumn{9}{|c|}{$R_{(t)}-R F_{(t)}=\alpha+b\left[R M_{(t)}-R F_{(t)}\right]+s S M B_{(t)}+h H M L_{(t)}+r R M W_{(t)}+c C M A_{(t)}+e_{(t)}$} \\
\hline Portfolio & $\alpha$ & b & $\mathbf{s}$ & h & $r$ & c & $\mathbf{F}$ & Adj. $R^{2}$ \\
\hline$S L-R F$ & 0.012 & 0.517 & 0.970 & -0.948 & -0.030 & 1.085 & $45.405^{*}$ & 0.757 \\
\hline
\end{tabular}




\begin{tabular}{|c|c|c|c|c|c|c|c|c|}
\hline & 0.005 & $4.379 *$ & 3.739* & $-4.570^{*}$ & -0.106 & $3.027^{*}$ & & \\
\hline \multirow[t]{2}{*}{ SM - RF } & 0.006 & 0.425 & 0.782 & 0.261 & -0.052 & 0.266 & $16.576^{*}$ & 0.523 \\
\hline & 0.003 & $4.613^{*}$ & $4.208 *$ & $2.676^{*}$ & -0.310 & 1.197 & & \\
\hline \multirow[t]{2}{*}{ SH - RF } & 0.008 & 0.457 & 0.776 & 0.392 & -0.038 & 0.563 & $17.800^{*}$ & 0.541 \\
\hline & 0.004 & $4.722 *$ & $4.402^{*}$ & $3.213^{*}$ & -0.205 & $2.338^{* *}$ & & \\
\hline \multirow[t]{2}{*}{$B L-R F$} & 0.008 & 0.398 & 0.098 & -0.166 & -0.036 & 0.148 & $11.115^{*}$ & 0.416 \\
\hline & 0.004 & $4.252^{*}$ & 0.834 & -1.505 & -0.254 & 0.768 & & \\
\hline \multirow[t]{2}{*}{ BM - RF } & 0.010 & 0.433 & 0.129 & 0.067 & -0.039 & 0.527 & $11.391^{*}$ & 0.423 \\
\hline & 0.004 & $4.349 *$ & 0.916 & 0.603 & -0.218 & $2.184^{* *}$ & & \\
\hline \multirow[t]{2}{*}{$\mathrm{BH}$ - RF } & 0.010 & 0.480 & 0.370 & 0.352 & -0.102 & 0.521 & $10.866^{*}$ & 0.410 \\
\hline & 0.005 & $4.577^{*}$ & $2.424 * *$ & $2.559 * *$ & -0.546 & $1.932^{* * *}$ & & \\
\hline \multirow[t]{2}{*}{ SR - RF } & 0.005 & 0.844 & 1.098 & 0.383 & -0.533 & 0.367 & $55.533^{*}$ & 0.793 \\
\hline & 0.004 & $13.442 *$ & $6.691 *$ & $3.408^{*}$ & $-3.885^{*}$ & $1.960 * * *$ & & \\
\hline \multirow[t]{2}{*}{ SW - RF } & 0.006 & 0.736 & 0.779 & 0.087 & 0.108 & 0.235 & $24.831 *$ & 0.627 \\
\hline & 0.005 & 9.965* & $4.033^{*}$ & 0.660 & 0.668 & 1.069 & & \\
\hline \multirow[t]{2}{*}{$B R-R F$} & -0.001 & 0.892 & 0.164 & 0.058 & -0.260 & 0.540 & $31.983^{*}$ & 0.686 \\
\hline & 0.005 & $12.002 *$ & 0.845 & 0.438 & -1.598 & $2.436^{* *}$ & & \\
\hline \multirow[t]{2}{*}{ BW- RF } & 0.009 & 0.824 & -0.037 & -0.037 & -0.086 & 0.226 & $57.156 *$ & 0.798 \\
\hline & 0.003 & $16.690^{*}$ & -0.287 & -0.424 & -0.796 & 1.536 & & \\
\hline \multirow[t]{2}{*}{$S C-R F$} & 0.009 & 0.818 & 1.183 & -0.016 & -0.062 & 1.115 & $87.933^{*}$ & 0.860 \\
\hline & 0.004 & $14.228 *$ & $7.870^{*}$ & -0.151 & -0.497 & $6.510^{*}$ & & \\
\hline \multirow[t]{2}{*}{$S A-R F$} & 0.005 & 0.795 & 1.120 & 0.062 & -0.076 & -0.222 & $42.446 *$ & 0.745 \\
\hline & 0.005 & $12.465^{*}$ & $6.717^{*}$ & 0.539 & -0.545 & -1.167 & & \\
\hline \multirow[t]{2}{*}{$B C-R F$} & 0.006 & 0.793 & 0.027 & 0.051 & -0.151 & 0.736 & $33.660 *$ & 0.697 \\
\hline & 0.005 & $12.152 *$ & 0.156 & 0.438 & -1.061 & $3.786 *$ & & \\
\hline \multirow[t]{3}{*}{ BA - RF } & 0.010 & 0.815 & 0.089 & -0.026 & -0.138 & 0.073 & $38.913 *$ & 0.728 \\
\hline & 0.004 & $13.726 *$ & 0.573 & -0.243 & -1.061 & 0.411 & & \\
\hline & & GRS -F : & 1.357 & & p-value: & 0.196 & & \\
\hline
\end{tabular}

Note: The values below $\alpha$ coefficient represent standard errors and the values below $b, s, h, r, c$ coefficients represent $t$-statistics. The standard errors of predicted parameters are adjusted against autocorrelation and heteroscedasticity by using Newey-West HAC correction. $\left({ }^{*}\right)\left({ }^{* *}\right)\left({ }^{* * *}\right)$ respectively indicate $\% 1, \% 5$ ve $\% 10$ significance levels.

Table 3 shows the performance comparison of the models. The performances are compared by the means of average absolute value of alpha, adjusted $R^{2}$ value and GRS-F test value, respectively.

Table 3: Comparison of Models

\begin{tabular}{lccc}
\hline \multicolumn{1}{c}{ Model } & A $|\alpha|$ & Adj. R & GRS-F \\
\hline Fama-French Five Factor Model & 0.008 & 0.643 & 1.357 \\
& & & $\mathbf{0 . 1 9 6}$ \\
Four-Factor Model & 0.008 & 0.622 & 1.465 \\
(Fama-French Five Factor Model excluding HML Factor) & & & $\mathbf{0 . 1 4 3}$ \\
\hline
\end{tabular}

The average absolute value of alpha value is 0.008 for both models. So that it doesn't give distinctive information about performance. Adjusted $R^{2}$ value is 0.643 for Fama-French five factor model whereas it is calculated 0.622 for four-factor model. Nevertheless, the apparent difference is observed in GRS-F values. Fama-French five factor has 1.357 GRS-F test value with 0.196 probability but it is calculated 1.465 with 0.143 probability for four-factor model. As a result, the findings exhibit that HML factor is not redundant in FamaFrench five factor model. 


\section{CONCLUSION}

Newly proposed asset pricing models are very popular in finance literature. However new models are less explored for developing markets. For that purpose, I investigate the new model of Fama and French (2015) and the necessity of value factor in the model between July 2009 and June 2015 in Istanbul Stock Exchange.

The main result is that Fama-French five factor model is an applicable and valid model in ISE. On the other hand, the factor premiums are not as high as Fama and French (2015) findings. The market return provides the highest premium in 72 month analysis period whereas firm size premium has almost vanished. It seems like $\mathrm{HML}$ is not a redundant factor in explaining common variation in stock returns at least in analysis period. For future research, the necessity of value factor may be scrutinized for a longer time period and also subperiods.

\section{REFERENCES}

Acaravci, K.S. \& Karaomer, Y .(2017). Fama-French five factor model: evidence from Turkey. International Journal of Economics and Financial Issues, Econjournals. 7(6): 130-137.

Aragon, G. O., Mehra, R., \& Wahal, S. (2018). Do Properly Anticipated Prices Fluctuate Randomly? Evidence from VIX Futures Markets (No. w24575). National Bureau of Economic Research.

Cakıcı, N. (2015).The five-factor Fama-French Model: international evidence. Working Paper, Fordham University. DOI: http://dx.doi.org/10.2139/ssrn.2601662

Chiah, M., Chai, D., Zhong, A., \& Li, S. (2016). A Better Model? An empirical investigation of the Fama-French five-factor model in Australia. International Review of Finance, 16(4), 595-638.

Fama, E. F., \& French K. R. (1993). Common risk factors in the returns on stocks and bonds, Journal of Financial Economics, 33 (1): 3-56. DOI: https://doi.org/10.1016/0304-405X(93)90023-5.

Fama, E. F., \& French K. R. (1996). Multifactor explanations of asset pricing anomalies.The Journal of Finance, 51 (1): $55-84$. DOI: https://doi.org/10.1111/j.1540-6261.1996.tb05202.x

Fama, E. F., \& French K. R. (2013). A four-factor model for the size, value, and profitability patterns in stock returns. Fama-Miller Working Paper, University of Chicago.

Fama, E. F., \& French K. R. (2015). A five-factor asset pricing model. Journal of Financial Economics, 116 (1): 1-22.

Fama, E. F., \& French K. R. (2016). Dissecting anomalies with a five factor model. The Review of Financial Studies, 29 (1): 69-103.DOI: https://doi.org/10.1093/rfs/hhv043

Fama, E. F., \& French K. R. (2017). International tests of a five-factor asset pricing model. Journal of Financial Economics, 123 (3): $441-463$. DOI: https://doi.org/10.1016/j.jfineco.2016.11.004

Foye, J. (2018). A comprehensive test of the Fama-French five-factor model in emerging markets. Emerging Markets Review.

Gibbons, M.R., Ross, S.A., Shanken, J. (1989), A test of the efficiency of a given portfolio. Econometrica, 57: $1121-1152$. DOI: $10.2307 / 1913625$

Lin, Q., (2017). Noisy prices and the Fama-French five-factor asset pricing model in China. Emerg. Mark. Rev., 31: 141-163.

Nguyen, D. M. (2016). Fama-French Five-factor model: Evidence from Vietnam. https://www.nzfc.ac.nz/archives/2016/papers/updated/49.pdf (02.12.2018)

White H. (1990). A heteroscedasticity consistent covariance matrix estimator and a direct test of heteroscedasticity. Econometrica, 48: 817838. DOI: $10.2307 / 1912934$

Yang, Q., Li, L., Zhu, Q., \& Mizrach, B. (2017). Analysis of US Sector of Services with a New Fama-French 5-Factor Model. Applied Mathematics, 8 (09), 1307. 